\title{
The Impact of Capital Structure on Firm Performance: Evidence from Vietnam*
}

\author{
Hieu Thanh NGUYEN**, Anh Huu NGUYEN**** \\ Received: February 24, 2020 Revised: March 1, $2020 \quad$ Accepted: March 6, 2020.
}

\begin{abstract}
This paper explores the impact of capital structure on firm performance in the context of Vietnam. The paper investigates the different effect of capital structure on firm performance in state-owned and non-state enterprises listed on the Vietnam stock market. The panel data of research sample includes 488 non-financial listed companies on the Vietnam stock market for a period of six years, from 2013 to 2018 . The Generalized Least Square (GLS) is employed to address econometric issues and to improve the accuracy of the regression coefficients. In this research, firm performance is measured by return on equity (ROE), return on assets (ROA), and earnings per share (EPS). The ratios of short-term liabilities, long-term liabilities, and total liabilities to total assets are proxy for capital structure. Firm sizes, growth rate, liquidity, and ratio of fixed assets to total assets are control variables in the study. The empirical results show that capital structure has a statistically significant negative effect on the firm performance. The result also shows this effect is stronger in state-owned enterprises than non-state enterprises in Vietnam. These evidences provide a new insight to managers of both state-owned and non-state enterprises on how to improve the firm's performance with capital structure.
\end{abstract}

Keywords: Capital Structure, Firm Performance, State-owned Enterprises, Non-state Enterprises, Vietnam

JEL Classification Code: G30, M40, M41

\section{Introduction}

Capital structure is one of the important decisions in the field of corporate finance and refer to the way that a company finances its assets by combining liabilities and equity (Gul \& Cho, 2019). Listed companies have the basic characteristic that different shareholders, thus forming the company's ownership structure, own equity capital. The

*This research is funded by the National Economics University (NEU), Hanoi, Vietnam. The authors thank anonymous referees for their contributions and the NEU for funding this research.

First Author and Corresponding Author. Lecturer, School of Accounting and Auditing, National Economics University, Vietnam. [Postal Address: 207 Giai Phong, Dong Tam, Hai Ba Trung, Hanoi, 113068, Vietnam] Email: hieu39ktqd@gmail.com

**Dean, School of Accounting and Auditing, National Economics University, Vietnam. Email: anhnh@neu.edu.vn

(c) Copyright: The Author(s)

This is an Open Access article distributed under the terms of the Creative Commons Attribution Non-Commercial License (http://Creativecommons.org/licenses/by-nc/4.0/) which permits unrestricted noncommercial use, distribution, and reproduction in any medium, provided the original work is properly cited. study of the impact of ownership structure on firm performance is a necessary research topic. Research on ownership structures in developing countries, especially those with the participation of state ownership, such as Eastern European countries, China, and Vietnam, has their own particularities. State ownership in these countries often has a high rate of visibility after the economy is transformed from a centrally-located economy, which shows the state's intervention in the activities of companies in the background economy. Accordingly, the empirical research on the impact of state ownership on the performance of the company is-varies in the different research (Xu \& Wang, 1999). There has been much debate on the effect of government ownership on firm performance. On the one hand, state ownership is claimed to bring a 'helping hand', which assumes that the higher involvement of state ownership in a firm, the more capital subsidy is provided by the government. On the other hand, state ownership is supposed to bring a 'grabbing hand', which assumes that the government will extract more of the firm's 
profit as a result of its ownership to the benefit of politicians and bureaucrats (Tian \& Estrin, 2008). Theoretically, Huang and Xiao (2012) argue for a net negative effect of government ownership and propose that less state ownership will result in an improvement in firm profitability and productivity. Shleifer and Vishny (1994) develop a game-theory model assuming state ownership bringing subsidies and bribes between the government and firms. They argue that politicians, using the power of control to pursue political objectives, may damage firm performance with heavy regulation. Empirically, the evidence for this line of research is mixed. Some studies report a positive effect (Jiang, Laurenceson, \& Tang, 2008; Liao and Young, 2012; Xu \& Wang, 1999; Saad, 2010) or an inverse U-shape effect of government ownership on firm performance (Sun, Tong, \& Tong, 2002), while some studies present a negative effect (Chen, Chen, Lin, \& Zhong, 2005; Lin, Ma, \& Su, 2009; Qi, Wu, \& Zhang, 2000; Wei, 2007) or a U-shape of state ownership on firm performance (Gunasekarage, Hess, \& Hu, 2007; Hess, Gunasekarage, \& Hovey, 2010; Ng, Yuce, \& Chen, 2009; Tian \& Estrin, 2008; Wei \& Varela, 2003; Wei, Xie, \& Zhang, 2005).

In the context of Vietnam, the country has established a privatization program from 1992. One of the methods of privatization involves transforming SOEs into joint-stocks companies and then selling parts of their shares to employees or private investors. Small or medium-sized SOEs, profitable or at least potentially profitable, but not "strategic enterprises", are the targets in the first stage of the Vietnamese privatization process, and then the scope of privatization extends to all non-strategic small and mediumsized SOEs (Truong, Lanjouw, \& Lensink, 2006). The Vietnamese government still holds a large fraction of ownership in formerly large state-owned economic enterprises/state corporation as well as firms in strategic sectors, namely mining, quarrying, electricity, oil and gas. This practice raises the question of the effect of state ownership on firm performance in the context of Vietnam.

The objective of this study is to find evidences on the relationship between capital structure and performance of state-owned companies and non-state companies listed on the Vietnam stock market and present recommendations to state management agencies, business managers and related parties.

The remainder of the study is organized as follows. Section 2 provides a basic theory and literature review. Section 3 present the hypothesis development. Section 4 describes the research methodology. Section 5 shows empirical results. Section 6 discusses the results and provides some recommendations. Section 7 represents the conclusion of the research.

\section{Basic Theory and Literature Review}

\subsection{Basic Theory}

Theories related to the selection of capital structure in enterprises are diverse, namely, Modigliani and Miller theory, trade-off theory, Pecking order theory, and market timing theory. Many scholars have tried to find empirical evidences to support these theories over the years.

Modigliani and Miller theory: The most fundamental theory for the structure of capital is possibly the theory expounded by of Modigliani and Miller (1958); Modigliani and Miller (1963). Assuming that corporate income tax rate is zero, the authors (Modigliani and Miller ,1958) claim that capital structure is irrelevant to firm's value or the firm has no way to increase its value by changing the capital structure. By including corporate income tax into the research model, Modigliani and Miller (1963) conclude that the value of firms, which have more debt in their capital structure, is equal to the market value of firms that do not have debt in their capital structure plus what is known as the "tax shield". In summary, Modigliani and Miller (1963) show that capital structure influences the firm's market value.

Trade-off theory: In order to complete the theory of Modigliani and Miller (1963), a number of tater studies have included financial distress and agency costs, for example, Kraus and Litzenberger (1973); Jensen and Meckling (1976) formally address the trade-off theory by concluding that the market value of a firm with debt equal to the value of a company without debt plus the value of tax shield minus the present value of bankruptcy costs. This means that the benefits of tax shield gained from debts will be offset against losses in case of bankruptcy. In a nutshell, this theory suggests that there exists an optimal capital structure for businesses, in which the benefit of tax shield best compensates for the losses from debts, such as financial distress and agency costs.

Pecking order theory: Pecking order theory explains financing decisions of business managers. Given the need for capital, businesses put an order of priority for their funds: they first use internal capital (e.g., internal funds, retained earnings), followed by loans (e.g., debt securities), and finally, and new equity. This results from the information asymmetry between company owners and external investors. While owners are fully aware of the firm's financial situation, external investors are poorly informed, and therefore, they are always skeptical about completeness and truthfulness of the information provided by the company owners. Therefore, companies often pay higher costs for external finance. The pecking order theory states that internal capital will always be preferred to loans and the use of internal funds will reduce the dependence of 
enterprises on external parties, increase financial autonomy and reduce the leakage of internal information.

\subsection{Literature Review}

Chang, Wang, Lee, and La (2014) studied the relationship between financial structure and performance of non-financial companies listed on Ho Chi Minh Stock Exchange in Vietnam from 2007 to 2011. This period covers the time before, during and after the global economic crisis, which originated from the US before hitting other countries, including Vietnam. The paper measured profitability by ROA, ROE, and Tobin'Q (calculated by the market price of equity plus book value of liabilities divided by total assets) and MBVR (market to book value ratio). Financial structure is measured by the ratios of short-term debt, long-term debt, and total debt to total assets. Control variables are firm size, ratio of fixed assets to total assets, and corporate income tax rate. The authors employed FEM, REM and OLS regression techniques and Hausman test to select FEM model to conclude on the relationship between capital structure and performance. They indicated a negative correlation between debt (including short-term debt, long-term debt and total debt) and ROA. Firm size is statistically positively related to ROA in all forms of capital structure. A negative relation exists between the ratio of fixed assets to total assets and ROA. Tax rate is weakly significant to ROA (in both longterm debt and total debt models) and statistically insignificant in the short-term debt model. Having ROE as a measure of business results, the research reported that the ratios of short-term debt and total debt to total assets are negatively related to ROE, while long-term debt is insignificant to ROE. Firm size is positively related to ROE in all models of short-term debt, long-term debt and total debt. The ratio of tangible fixed assets is statistically significant and negatively related to ROE in the short-term debt model. Tax rate is statistically insignificant to ROE in all research models. Vijayakumaran and Vijayakumaran (2019) state that to prevents dilution of equity ownership of insiders and give more monitoring from the debt holders, the company should use more debt financing. This can lead to increase firm value by reducing agency costs of equity.

Ramadan and Ramadan (2015) identified the effect of capital structure on the performance of 72 companies listed on the Amman Stock Exchange during the period between 2005 and 2013. The authors used ROA as a measure of profitability and the ratios of long-term debt to total assets and total debt to total assets as indicators of capital structure. Applying OLS regression, the authors stated that debt ratios are negatively related to performance. Wellperforming firms are less dependent on credit. This result is consistent with the Pecking-order theory when companies prefer equity.

Claessen, Djankov, and Lang (2000) investigate the separation of ownership and control in 2980 public companies in nine East Asian countries. Their findings suggest that corporate control is typically enhanced pyramids structure and cross holding companies in all East Asian countries except Singapore where about half of the sample companies are controlled by state.

Orden and Garmendia (2005) examined the relationship between ownership structure and corporate performance in Spanish companies. Ownership structure has been analysed in terms of concentration of control and the type of investor exerting control. Company performances, which used in research, were return on assets (ROA) and return on equity (ROE). One of hypotheses findings is that companies, under government control showed negative impact and have worse performance than other ownership structures.

Kumar (2003) compared the financial performance of state-owned, private-owned, and mixed state-private ownership companies in India from 1973 to 1989. Findings appear to be differing from Singapore-based study, and suggest that the most profitable companies were the privatlye-owned ones followed by those under mixed ownership. While state-owned enterprises had the worst performance. Most other studies in India and abroad draw similar conclusions (Shleifer \& Vishny, 1997; Shleifer, 1998). Meanwhile, in China, Tian and Estrin (2005) find that government ownership reduced corporate value due to political interference. Also, in other paper written by $\mathrm{Xu}$ and Wang (1999) found that government enterprise performed worse in profitability than non-government enterprise. Wei, Xie and Zhang (2005) examines the performance of domestic Chinese companies in various ownership categories versus foreign-invested enterprises (FIEs) based on two nation-wide surveys conducted by the National Bureau of Statistics in 1998 and 2002. It was found that both domestic non-state-owned companies and foreign-invested enterprises performed better than stateowned enterprises.

Based on the literature review, the following research gaps are pointed out:

First, the sign of leverage and profitability relationship is inconsistent in the studies. Empirical studies from different economies, at different times and different research methods bring diverse and mixed research results. Therefore, this topic needs further research to enrich the empirical evidences especially accounted for structure ownership.

Second, there are various papers on the relationship between capital structure and firm performance in a wide range of countries such as Sri Lanka (Prahalathan \& Ranjani, 2011; Nirajini \& Priya, 2013; Logavathani \& 
Lingesiya, 2018), Pakistan (Khan, 2012), Iran (Nikoo, 2015), Jordan (Taani, 2013; Ramadan \& Ramadan, 2015), Kenya (Yogen, Cheruiyot, Sang, \& Cheruiyot, 2014; Renoh \& Ntoiti, 2015), Bangladesh (Siddik, Kabiraj, \& Joghee, 2017), Malaysia (Mahfuzah \& Raj, 2012). However, there are only a few studies in Vietnam (Chang, Wang, Lee, \& La, 2014; Nguyen \& Nguyen, 2020).

\section{Hypothesis Development}

First, the ratio of total debt to total assets gives investors an overview of the financial strength and capital structure of a business and how it finances the operations. In principle, the lower this ratio is, meaning that liabilities account for a small proportion of total assets, the less financial risk the business exposes. A higher ratio reflects a riskier funding structure and a greater chance of insolvency and bankruptcy. There are different studies examining this relationship, such as Mahfuzah and Raj (2012), Logavathani and Lingesiya (2018), Nguyen and Nguyen (2020) who concluded that the ratio of total debt to total assets is inversely proportional to business performance, i.e., increasing the debt ratio would result in less profitable businesses. In contrast, other studies exist, showing a positive correlation (Arbabiyan and Safari, 2009), no correlation (Chang, Wang, Lee, \& La, 2014; Prahalathan \& Ranjani, 2011) or a weak correlation (Khan, 2012) between these factors. In the case of firms listed on Vietnam's stock market, how is profitability and leverage related? This question brings puts the authors to formulate the first hypothesis.

H1: There is a negative relationship between the ratio of total debt to total assets and performance of listed companies in Vietnam.

Second, liabilities can be categorized into short-term debts and long-term debts. Theoretically, companies using short-term debts must regularly replicate the cycle of repaying old debts and borrowing new ones. Short-term debts are sensitive to market interest rates, causing instability in the use of capital. On the other hand, interest rates of long-term debt are more stable. Abor (2005), Arbabiyan and Safari (2009) found a positive correlation between the ratio of short-term debt to total assets and business performance and an inverse correlation between the ratio of long-term debt to total assets and business outcomes (measured by ROE). Meanwhile, Chang, Wang, Lee, and La (2014) discussed the ratio of short-term debt to total assets is negatively related to ROE while long-term debt is statistically insignificant to ROE. Prahalathan and Ranjani (2011) concluded the ratios of short-term debt, long-term debt and total debt to total assets are insignificant to both ROE and ROA. Khan (2012) suggested the ratios of short-term debt, long-term debt and total debt to total assets are weakly related to ROE. In the context of Vietnam, in order to determine the relationship between short-term debt and/or long-term debt to business performance, the following two hypotheses are formulated:

H2: There is a negative relationship between the ratio of long-term debt to total assets and performance of listed companies in Vietnam.

H3: There is a negative relationship between the ratio of short-term debt to total assets and performance of listed companies in Vietnam.

\section{Research Methodology}

\subsection{Data Collection}

The study used panel data collected from 488 nonfinancial companies listed on the Stock Exchange over a six-year period, from 2013 to 2018, provided by FiinGroup JSC. Research data is extracted from the audited financial statements of these companies. In this research, state-owned companies are companies with $50 \%$ or more of the state capital, and non-state companies are the remaining companies with less than $50 \%$ of the state capital. The sample includes 116 state-owned companies and 372 nonstate companies.

\subsection{Research Model}

The impact of capital structure on firm performance is shown in the following three models:

ROA Models: ROA models include three sub-models: STD, LTD and TD model as follow:

$$
\begin{aligned}
& \mathrm{ROA}_{\mathrm{i}, \mathrm{t}=\alpha 0}+\alpha_{1} \mathrm{CL}_{\mathrm{i}, \mathrm{t}}+\alpha_{2} \mathrm{TANG}_{\mathrm{i}, \mathrm{t}}+\alpha_{3} \mathrm{SG}_{\mathrm{i}, \mathrm{t}}+\alpha_{4} \mathrm{SIZE}_{\mathrm{i}, \mathrm{t}}+ \\
& \alpha_{5} \mathrm{LIQ}_{\mathrm{i}, \mathrm{t}}+\varepsilon_{\mathrm{i}, \mathrm{t}} \\
& \mathrm{ROA}_{\mathrm{i}, \mathrm{t}}=\beta_{0}+\beta_{1} \mathrm{LL}_{\mathrm{i}, \mathrm{t}}+\beta_{2} \mathrm{TANG}_{\mathrm{i}, \mathrm{t}}+\beta_{3} \mathrm{SG}_{\mathrm{i}, \mathrm{t}}+\beta_{4} \mathrm{SIZE}_{\mathrm{i}, \mathrm{t}} \\
& +\beta_{5} \mathrm{LIQ}_{\mathrm{i}, \mathrm{t}}+\varepsilon_{\mathrm{i}, \mathrm{t}} \\
& \mathrm{ROA}_{\mathrm{i}, \mathrm{t}}=£_{0}+£_{1} \mathrm{TL}_{\mathrm{i}, \mathrm{t}}+£_{2} \mathrm{TANG}_{\mathrm{i}, \mathrm{t}}+£_{3} \mathrm{SG}_{\mathrm{i}, \mathrm{t}}+\underbrace{}_{4} \mathrm{SIZE}_{\mathrm{i}, \mathrm{t}}+ \\
& £_{5} \mathrm{LIQ}_{\mathrm{i}, \mathrm{t}}+\varepsilon_{\mathrm{i}, \mathrm{t}}
\end{aligned}
$$

ROE Models: ROE models include three sub-models: STD, LTD and TD model as follow: 


$$
\begin{aligned}
& \operatorname{ROE}_{\mathrm{i}, \mathrm{t}}=\alpha_{0}+\alpha_{1} \mathrm{CL}_{\mathrm{i}, \mathrm{t}}+\alpha_{2} \mathrm{TANG}_{\mathrm{i}, \mathrm{t}}+\alpha_{3} \mathrm{SG}_{\mathrm{i}, \mathrm{t}}+\alpha_{4} \mathrm{SIZE}_{\mathrm{i}, \mathrm{t}}+ \\
& \alpha_{5} \mathrm{LIQ}_{\mathrm{i}, \mathrm{t}}+\varepsilon_{\mathrm{i}, \mathrm{t}} \\
& \mathrm{ROE}_{\mathrm{i}, \mathrm{t}}=\beta_{0}+\beta_{1} \mathrm{LL}_{\mathrm{i}, \mathrm{t}}+\beta_{2} \mathrm{TANG}_{\mathrm{i}, \mathrm{t}}+\beta_{3} \mathrm{SG}_{\mathrm{i}, \mathrm{t}}+\beta_{4} \mathrm{SIZE}_{\mathrm{i}, \mathrm{t}}+ \\
& \beta_{5} \mathrm{LIQ}_{\mathrm{i}, \mathrm{t}}+\varepsilon_{\mathrm{i}, \mathrm{t}} \\
& \mathrm{ROE}_{\mathrm{i}, \mathrm{t}}=£_{0}+£_{1} \mathrm{TL}_{\mathrm{i}, \mathrm{t}}+£_{2} \mathrm{TANG}_{\mathrm{i}, \mathrm{t}}+£_{3} \mathrm{SG}_{\mathrm{i}, \mathrm{t}}+£_{4} \mathrm{SIZE}_{\mathrm{i}, \mathrm{t}}+ \\
& £_{5} \mathrm{LIQ}_{\mathrm{i}, \mathrm{t}}+\varepsilon_{\mathrm{i}, \mathrm{t}}
\end{aligned}
$$

EPS Models: EPS models include three sub-models: STD, LTD and TD model as follow:

$$
\begin{aligned}
& \mathrm{EPS}_{\mathrm{i}, \mathrm{t}}=\alpha_{0}+\alpha_{1} \mathrm{CL}_{\mathrm{t}, \mathrm{t}}+\alpha_{2} \mathrm{TANG}_{\mathrm{i}, \mathrm{t}}+\alpha_{3} \mathrm{SG}_{\mathrm{i}, \mathrm{t}}+\alpha_{4} \mathrm{SIZE}_{\mathrm{i}, \mathrm{t}}+ \\
& \alpha_{5} \mathrm{LIQ}_{\mathrm{i}, \mathrm{t}}+\varepsilon_{\mathrm{i}, \mathrm{t}} \\
& \mathrm{EPS}_{\mathrm{i}, \mathrm{t}}=\beta_{0}+\beta_{1} \mathrm{LL}_{\mathrm{i}, \mathrm{t}}+\beta_{2} \mathrm{TANG}_{\mathrm{i}, \mathrm{t}}+\beta_{3} \mathrm{SG}_{\mathrm{i}, \mathrm{t}}+\beta_{4} \mathrm{SIZE}_{\mathrm{i}, \mathrm{t}}+ \\
& \beta_{5} \mathrm{LIQ}_{\mathrm{i}, \mathrm{t}}+\varepsilon_{\mathrm{i}, \mathrm{t}}
\end{aligned}
$$

\begin{tabular}{|c|c|c|}
\hline Variables & Variable name & Measurement \\
\hline ROE & Return on equity & Net Income/Stockholders` Equity \\
\hline ROA & Return on asset & Net Income/Total Assets \\
\hline EPS & Earnings per share & $\begin{array}{l}\text { (Net Income - Prefered } \\
\text { Dividend)/(Weighted average } \\
\text { commom stock outstanding) }\end{array}$ \\
\hline CL & $\begin{array}{l}\text { Short-term debt to } \\
\text { total assets }\end{array}$ & Short Term Debt/Total Assets \\
\hline LL & $\begin{array}{l}\text { Long term debt to } \\
\text { total assets }\end{array}$ & Long Term Debt/Total Assets \\
\hline $\mathrm{TL}$ & $\begin{array}{l}\text { Total debt to total } \\
\text { assets }\end{array}$ & Total Debt/Total Assets \\
\hline TANG & Tangibility & Fixed Assets/Total Assets \\
\hline SG & Sale growth & $\begin{array}{c}\left(\text { Net Sale }_{t}-\text { Net Slale }_{\mathrm{t}-1}\right) / \text { Net } \\
\text { Sale }_{t}\end{array}$ \\
\hline Size & Firm size & Logarit (Total Assets) \\
\hline LIQ & Liquidity & Current Assets/Short Term Debt \\
\hline
\end{tabular}

\begin{tabular}{|c|c|c|c|c|c|c|}
\hline \multirow{2}{*}{$\begin{array}{c}\text { Model } \\
\text { ROA }\end{array}$} & \multicolumn{3}{|c|}{ State-owned companies } & \multicolumn{3}{|c|}{ Non-state companies } \\
\hline & (1) & (2) & (3) & (1) & (2) & (3) \\
\hline $\mathrm{CL}$ & $-0.194 * * *$ & & & $-0.140 * * *$ & & \\
\hline LL & & $-0.183^{* * *}$ & & & $-0.144 * * *$ & \\
\hline $\mathrm{TL}$ & & & $-0.243^{* * *}$ & & & $-0.169 * * *$ \\
\hline SIZE & 0.00203 & $0.00473 * *$ & $0.00858 * * *$ & $0.00343 * * *$ & $0.00547 * * *$ & $0.00932 * * *$ \\
\hline TANG & $-0.0708 * * *$ & $0.0448 * * *$ & $-0.0435 * * *$ & $-0.0505 * * *$ & $0.0455^{* * *}$ & $-0.0148^{* *}$ \\
\hline GROWTH & 0.000113 & 0.000283 & 0.000128 & $0.00229 * * *$ & $0.00213 * * *$ & $0.00226^{* * *}$ \\
\hline LIQ & $0.00392 * *$ & $0.0129 * * *$ & 0.000601 & $-0.000450 *$ & $0.000983 * * *$ & $-0.000779 * * *$ \\
\hline Constant & $0.107^{* *}$ & -0.0834 & -0.0292 & 0.0382 & $-0.0889 * * *$ & $-0.103 * * *$ \\
\hline
\end{tabular}

$$
\text { EPS }_{i, t}=£_{0}+£_{1} \mathrm{TL}_{\mathrm{i}, \mathrm{t}}+£_{2} \mathrm{TANG}_{\mathrm{i}, \mathrm{t}}+£_{3} \mathrm{SG}_{\mathrm{i}, \mathrm{t}}+£_{4} \mathrm{SIZE}_{\mathrm{i}, \mathrm{t}}+
$$

$£_{5} \mathrm{LIQ}_{\mathrm{i}, \mathrm{t}}+\varepsilon_{\mathrm{i}, \mathrm{t}}$

Table 1: Measurement of variables

\section{Empirical Results}

Table 2: GLS regression results of ROA model

$*, * *, * * *$ indicated respectively the significance at $10 \%, 5 \%$ and $1 \%$ levels

The regression coefficient obtained by the GLS regression method shows that: in state-owned enterprises, the capital structure (as measured by the ratio of short-term debt to total assets, long-term debt to total assets and total debt on the total assets) is negatively related to the ROA (shown in the regression coefficients received negative values in models 1,2 and 3 are $-0.194 ;-0.183$ and -0.243 . In non-state companies, the regression coefficients also received negative values of $-0.140 ;-0.144$ and -0.169 respectively.
It can be seen that the variable TANG is different in the equations of each debt ratio component when classified by ownership type. With the presence of long-term debt ratio, the relationship between TANG and LIQ on ROA becomes overwhelming and changes in beta. Therefore, in the research results with long-term debt ratio, the variable TANG, LIQ will be evaluated as unreliable. Therefore, in these cases, the impact of TANG, LIQ will be considered as the impact from the equations of other CL or TL variables. 
Table 3: GLS regression results of ROE model

\begin{tabular}{|c|c|c|c|c|c|c|}
\hline \multirow{2}{*}{$\begin{array}{c}\text { Model } \\
\text { ROE }\end{array}$} & \multicolumn{3}{|c|}{ State-owned companies } & \multicolumn{3}{|c|}{ Non-state companies } \\
\hline & (4) & (5) & (6) & (4) & (5) & (6) \\
\hline $\mathrm{CL}$ & $-0.181 * * *$ & & & $-0.127 * * *$ & & \\
\hline LL & & $-0.198 * * *$ & & & $-0.150 * * *$ & \\
\hline TL & & & $-0.238^{* * *}$ & & & $-0.159 * * *$ \\
\hline SIZE & $0.00637^{*}$ & $0.00956^{* * *}$ & $0.0129 * * *$ & $0.0121 * * *$ & $0.0146^{* * *}$ & $0.0178 * * *$ \\
\hline TANG & $-0.0919 * * *$ & 0.0211 & $-0.0690 * * *$ & $-0.0650 * * *$ & 0.0280 & $-0.0332 * *$ \\
\hline GROWTH & 0.000319 & 0.000483 & 0.000327 & $0.00472 * * *$ & $0.00457 * * *$ & $0.00469 * * *$ \\
\hline LIQ & 0.00125 & $0.00949 * * *$ & -0.00245 & $-0.00103 *$ & 0.000275 & $-0.00139 * * *$ \\
\hline Constant & 0.0518 & -0.143 & -0.0777 & $-0.145^{* *}$ & $-0.277 * * *$ & $-0.278 * * *$ \\
\hline
\end{tabular}

$*, * *, * *$ indicated respectively the significance at $10 \%, 5 \%$ and $1 \%$ levels

The regression coefficient obtained by the GLS regression method shows that:, in state-owned enterprises, the capital structure (as measured by the ratio of short-term debt to total assets, long-term debt to total assets and total debt on the total assets) is negatively related to the ROE (shown in the regression coefficients received negative values in models 1,2 and 3 are $-0.181 ;-0.198$ and -0.238 . In non-state companies, the regression coefficients also received negative values of $-0.127 ;-0.15$ and -0.159 respectively.

Besides, the effect of firm size (SIZE) on ROE is positive (shown in positive regression coefficients); The effect of the ratio of fixed assets to total assets (TANG) with ROE is opposite (shown in the negative regression coefficient); The effect of growth rate (GROWTH) with ROE is in the same direction (shown in positive regression coefficients) in both state and non-state enterprises. Particularly, for the solvency of the company (LIQ), the influence of LIQ on ROE in State-owned enterprises is in the same direction (positive regression coefficient) but in non-State enterprises is in the opposite direction (negative regression coefficient). These relationships are statistically significant (p-value $<0.01$ ).

Table 4: GLS regression results of EPS model

\begin{tabular}{|c|c|c|c|c|c|c|}
\hline \multirow{2}{*}{$\begin{array}{c}\text { Model } \\
\text { EPS }\end{array}$} & \multicolumn{3}{|c|}{ State-owned companies } & \multicolumn{3}{|c|}{ Non-state companies } \\
\hline & (7) & (8) & (9) & (7) & $(8)$ & (9) \\
\hline CL & $-4,534 * * *$ & & & $-2,211 * * *$ & & \\
\hline LL & & $-3,963 * * *$ & & & $-4,305^{* * *}$ & \\
\hline $\mathrm{TL}$ & & & $-5,554 * * *$ & & & $-3,304 * * *$ \\
\hline SIZE & $247.4 * * *$ & $302.5 * * *$ & $395.9 * * *$ & $400.4 * * *$ & $498.2 * * *$ & $524.0 * * *$ \\
\hline TANG & $-3,198 * * *$ & -558.0 & $-2,532 * * *$ & $-1,537 * * *$ & $564.5^{*}$ & $-1,052 * * *$ \\
\hline GROWTH & 1.243 & 5.164 & 1.669 & 32.32 & 29.12 & 32.16 \\
\hline LIQ & 92.02 & $302.7 * * *$ & 21.39 & -14.86 & 10.78 & $-28.67 * * *$ \\
\hline Constant & $-1,552$ & $-5,794 * *$ & $-4,695 * *$ & $-7,268 * * *$ & $-11,025 * * *$ & $-9,965 * * *$ \\
\hline
\end{tabular}

$*, * *, * * *$ indicated respectively the significance at $10 \%, 5 \%$ and $1 \%$ level.

The regression coefficient obtained by the GLS regression method shows that;, in state-owned enterprises, the capital structure (as measured by the ratio of short-term debt to total assets, long-term debt to total assets and total debt on the total assets) is negatively related to the ROE (shown in the regression coefficients received negative values in models 1,2 and 3 are -4,534; -3,963 and -5,554. In non-state companies, the regression coefficients also received negative values of $-2,211 ;-4,305$ and $-3,304$ respectively.

Similar to the ROE model, the effect of firm size on EPS is in the same direction (negative regression coefficients), and TANG's effect on EPS is in the opposite direction (shown in negative regression coefficients). However, unlike the ROE model, in the EPS model, the relationship between GROWTH and EPS is not statistically significant, there is no basis for concluding there is a 
relationship between GROWTH and EPS. Similar to the ROE model, the relationship between LIQ and EPS is in the same direction for SOEs, but opposite.

\section{Discussion and Recommendations}

\subsection{Discussion}

First, the increase in debt (both short-term debt, longterm debt, total debt) has a negative effect on the business results of the business. This effect is greater in SOEs and less in non-State enterprises. This result supports the results of Gunasekarage, Hess, and Hu (2007), Chang, Wang, Lee, and La (2014), Logavathani and Lingesiya (2018), and Nguyen and Nguyen (2020).

Second, the relationship between liabilities and business performance shows that the relationship between capital structure (debt size over total assets) in non-state-owned enterprises is more pronounced than in state-owned enterprises. Currently, the data representation of stateowned enterprises is very concentrated, while the datarepresentation of non-state enterprises is quite dispersed-). Therefore, the relationship between capital structure and the performance of state-owned enterprises may not be entirely linear. Further research is needed on the effect of capital structure on firm's business performance.

Third, the size of the company is positively related to the business results of both state and state enterprises.

Fourth, the liquidity of the company is positively related to the business results of state companies, but in the opposite direction to non-state companies.

Fifth, the growth rate of the company has a positive effect on the business results of both state-owned and nonstate enterprises.

Sixth, the proportion of fixed assets in total assets is negatively related to the business results of both stateowned enterprises and non-state enterprises.

\subsection{Recommendations}

The empirical results of this article show that company size (SIZE) is positively related to the company's business performance. The more companies scale up, the higher their performance (ROE, ROA, EPS) will be. When companies need to borrow capital to expand the size of the company, the state management agencies need to create favorable conditions for businesses to access capital. The state should consider policies on interest rates at a reasonable level so that businesses can both receive capital and bring business efficiency.

At the same time, the empirical research results show that companies with higher loan rates have lower business results. This logic with an analysis of the impact mechanism of high state ownership structure leads to high loan rates, but low firm performance. These empirical research results may prove to support the state management policies that tend to reduce state ownership and increase foreign ownership in companies in Vietnam.

As the company tends to borrow more, the company may be subject to the more supervision and supervision of creditors so the company's performance may increase. However, this relationship also depends on the level of information transparency of countries and the nature of the borrowing activities of the companies in the countries. For developed markets, borrowing is primarily borrowed directly on financial markets through the issuance of debt instruments. A well-developed market also means a better level of information transparency and ability to monitor creditors' operations with the company. Debt trading through the secondary market also helps the company and its creditors regularly assess the quality of debt, thereby making timely adjustments in business operations and public performance. For businesses operating in developed countries, the relationship between financial leverage and performance across the company is a positive relationship.

In contrast, for countries where the borrowing is primarily from commercial bank loans (Vietnam is a typical example), loan approval may not come from the very performance of purpose loans. However, due to many other factors, loans may increase in the companies themselves, but their performance is not high. In addition, the limited ability to monitor after-lending operations of commercial banks in these countries also increases the likelihood that companies do not really focus on efficient and proper use. Therefore, for developing countries like Vietnam, companies with high debt ratios may be proven inefficient companies.

The experimental results of this article show that increasing the ratio of liabilities to total assets will make the business performance of the company (ROE, ROA, EPS) decrease. At the same time, the revenue growth rate (GROWTH) has a good effect on business performance. Therefore, business managers need to take appropriate measures to use debt, help increase sales, but still ensure increased business performance.

\section{Conclusion}

In conclusion, through a set of data collected from 116 state-owned and 372 non-state listed companies, the authors analyzed the impact of capital structure on the business results of these two groups of companies. Empirical results from the GLS regression show that the increase in debt ratio has a negative effect on the business results of both 
types of state and non-state enterprises. However, the influence of capital structure on business results is stronger in state-owned enterprises. In addition, increasing the scale, and increasing the growth rate also helps in increasing business results of the enterprise. The research results of this article are useful for the state management agencies in issuing capital management policies and helping corporate managers in making effective business decisions.

\section{References}

Abor, J. (2005). The effect of capital structure on profitability: an empirical analysis of listed firms in Ghana. Journal of Risk Finance, 6(5), 438-445.

Arbabiyan, A.A., \& Safari, M. (2009). The effects of capital structure and profitability in the listed firms in Tehran stock exchange. Journal of Management Perspective, 33(1), 159175.

Chang, F.M., Wang, Y., Lee, N.R., \& La, D.T. (2014). Capital structure decisions and firm performance of Vietnamese Soes. Asian Economic and Financial Review, Asian Economic and Social Society, 4(11), 1545-1563.

Chen, S.K., Chen, X., Lin, B., \& Zhong, R. (2005). The impact of government regulation and ownership on the performance of securities companies: evidences from China. Global Finance Journal, 16(2), 113-124.

Claessen, S., Djankov, S., \& Lang, L.H.P. (2000). The separation of ownership and control in East Asian corporations. Journal of Financial Economics, 58(2) 81-112.

Gul, S., \& Cho, H.R. (2019). Capital structure and default risk: evidence from Korean stock Market. Journal of Asian Finance, Economics and Business, 6(2), 15-24. https://doi.org/10.13106/jafeb.2019.vol6.no2.15.

Gunasekarage, A., Hess, K., \& Hu, A.J. (2007). The influence of the degree of state ownership and the ownership concentration on the performance of listed Chinese companies. Research in International Business and Finance, 21(3), 379-395.

Huang, L., \& Xiao, S. (2012). How does government ownership affect firm performance? a simple model of privatization in transition economies. Economics Letters, 116(3), 480-482.

Hess, K., Gunasekarage, A., \& Hovey, M. (2010). State-dominant and non-state-dominant ownership concentration and firm performance: evidence from China. International Journal of Managerial Finance, 6(4), 264-289.

Jensen, M.C., \& Meckling, W.H. (1976). Theory of the firm: managerial behavior, agency costs and ownership structure. Journal of Financial Economics, 3(4), 305-360.

Jiang, B.B., Laurenceson, J., \& Tang, K.K. (2008). Share reform and the performance of China's listed companies. China Economic Review, 19(3), 489-501.

Khan, A.G. (2012). The relationship of capital structure decisions with firm performance: a study of the engineering sector of Pakistan. International Journal of Accounting and Financial Reporting, 2(1), 245-262.

Kraus, A., \& Litzenberger, R.H. (1973). A state-preference model of optimal financial leverage. The Journal of Finance, 28(4), 911-922.
Kumar, J. (2003). Does ownership structure influence firm value? evidence from India. The Journal of Entrepreneurial Finance and Business Ventures, 9(2), 61-93.

Liao, J., \& Young, M. (2012). The impact of residual government ownership in privatized firms: new evidence from China. Emerging Markets Review, 13(3), 338-351.

Lin, C., Ma, Y., \& Su, D. (2009). Corporate governance and firm efficiency: evidence from China's publicly listed firms. Managerial and Decision Economics, 30(3), 193-209.

Logavathani, S., \& Lingesiya, K. (2018). Capital structure and Financial performance: a study on commercial banks in Sri Lanka. Asian Economic and Financial Review, 8(5), 586-598.

Mahfuzah, S., \& Raj, Y. (2012). Capital structure and firm performance: evidence from Malaysian listed companies. Procedia-Social and Behavioral Sciences, 65(3), 156-166.

Modigliani, F., \& Miller, M.H. (1958). The cost of capital, corporation finance and the theory of investment. The American Economic Review, 48(3), 261-297.

Modigliani, F., \& Miller, M.H. (1963). Corporate income taxes and the cost of capital: a correction. The American Economic Review, 53(3), 433-443.

$\mathrm{Ng}$, A., Yuce, A., \& Chen, E. (2009). Determinants of state equity ownership, and its effect on value/performance: China's privatized firms. Pacific-Basin Finance Journal, 17(4), 413443.

Nguyen, T.H., \& Nguyen, H.A. (2020). Capital structure and firm performance of non-financial listed companies: cross-sector empirical evidences from Vietnam. Accounting, 6(2), 137-150.

Nikoo, S. F. (2015). Impact of capital structure on banking performance: evidence from Tehran stock exchange. International Research Journal of Applied and Basic Sciences, 9(6), 923-927.

Nirajini, A., \& Priya, K.B. (2013). Impact of capital structure on financial performance of the listed trading companies in Sri Lanka. International Journal of Scientific and Research publications, 3(5), 35-43.

Orden, O. D., \& Garmendia, A. (2005). Does it matter ownership structure? performance in Spanish companies. Journal of European Financial Management, 1-40.

Prahalathan, B., \& Ranjani, R.P.C. (2011). The impact of capital structure-choice on firm performance: empirical investigation of listed companies in Colombo stock exchange, Sri Lanka. International Journal of Research in Commerce \& Management, 2(4), 12-16.

Qi, D., Wu, W., \& Zhang, H. (2000). Shareholding structure and corporate performance of partially privatized firms: evidence from listed Chinese companies. Pacific-Basin Finance Journal, $8(5)$, 587-610.

Renoh, C., \& Ntoiti, J. (2015). Effect of capital structure on financial performance of listed commercial banks in Kenya: a case study of Kenya commercial banks limited. Strategic, Business \& Change Journal of Management, 2(72), 750-781.

Ramadan, Z.S., \& Ramadan, L.Z. (2015). Capital structure and firm's performance of Jordanian manufacturing sector. International Journal of Economics and Finance, 7(6), 279284.

Saad, N. M. (2010). Corporate governance compliance and the effects to capital structure. International Journal of Economics and Financial, 2(1), 105-114. 
Siddik, N. A., Kabiraj, S., \& Joghee, S. (2017). Impacts of capital structure on performance of banks in a developing economy: evidence from Bangladesh. International Journal of Financial Studies, 5(2), 1-18.

Sun, Q., Tong, W. H. S., \& Tong, J. (2002). How does government ownership affect firm performance? evidence from China's privatization experience. Journal of Business Finance \& Accounting, 29(1-2), 1-27.

Taani, K. (2013). The relationship between capital structure and firm performance: evidence from Jordan. Global Advanced Research Journal of Management and Business Studies, 2(11), 542-546.

Tian, L., \& Estrin, S. (2008). Retained state shareholding in Chinese PLCs: does government ownership always reduce corporate value? Journal of Comparative Economics, 36(1), 74-89.

Truong, D. L., Lanjouw, G., \& Lensink, R. (2006). The impact of privatization on firm performance in a transition economy: the case of Vietnam. Economics of Transition, 14(2), 349-389.

Shleifer, A. (1998). State versus private ownership. Journal of Economic Perspectives, 12(4), 133-150.

Shleifer, A., \& Vishny, R.W. (1994). Politicans and Firms. Quarterly Journal of Economics, 109(4), 995-1025.
Shleifer, A., \& Vishny, R.W. (1997). A survey of corporate governance. Journal of Finance, 52(2), 737-783.

Vijayakumaran, S., \& Vijayakumaran, R. (2019). Corporate governance and capital structure decisions: evidence from Chinese listed companies. Journal of Asian Finance, Economics and Business, 6(3), 67-79. https://doi.org/10.13106/jafeb.2019.vol6.no3.67.

Xu, X., \& Wang, Y. (1999). Ownership structure and corporate governance in Chinese stock companies. China Journal of Accounting Research, 6(2), 75-87.

Yogen, C. J., Cheruiyot, J., Sang, \& Cheruiyot, P. K. (2014). The effect of capital structure on firm's profitability: evidence from Kenya's banking sector. Research Journal of Finance \& Accounting, 5(9), 152-159.

Wei, G. (2007). Ownership structure, corporate governance and company performance in China. Asia Pacific Business Review, 13(4), 519-545.

Wei, Z.B., \& Varela, O. (2003). State equity ownership and firm market performance: evidence form China's newly privatized firms. Global Finance Journal, 14(1), 65-82.

Wei, Z.B., Xie, F.X., \& Zhang, S.R. (2005). Ownership structure and firm value in China's privatized firms: 1991-2001. Journal of Financial and Quantitative Analysis, 40(1), 87-108. 